\title{
Breeding for Yellow Seeded Ethiopian Mustard (Brassica Carinata) With High Seed Yield and Oil Content at Holetta Agricultural Research Center, Ethiopia
}

\author{
Misteru Tesfaye", Bulcha Weyessa, Tadesse Debele \\ Ethiopian Institute of Agricultural Research, Holetta Research Center, P.O.Box.2003, Addis Ababa, Ethiopia \\ *Corresponding Author: Misteru Tesfaye Woldeyohannes, Ethiopian Institute of Agricultural Research, \\ Holetta Research Center, P.O.Box.2003, Addis Ababa, Ethiopia
}

\begin{abstract}
Development of yellow seeded variety with high seed yield and oil content is one of the breeding objectives of Ethiopian mustard (Brassica carinata). In order to realize this objective, the breeding work had been stated from enhancement of the available gene pools through hybridization and recurrent selection. In line of this, target crossing was made among the adapted varieties and some introduced oilseed brassica sp. Selection was made at $F_{2}$ subsequent generation till $F_{5}$ along with single plant selection from the adapted and local landraces. During the second cycle of selection, the breeding lines were classified in terms of seed color (i.e. yellow, brown and mixed). Evaluation of selected lines for agro-morphological traits and selection for yellow seed colour were conducted simultaneously since the second cycle of recurrent selection. After the third cycle of selection, where 64 brassica genotypes identified, the extent of genetic variability, heritability and genetic advance were analyzed for agro-morphological traits of the selected genotypes. Multi-location trials was also conducted for the selected yellow seeded genotypes for two years (2015/16 and 2016/17). A considerable level of variability was noticed for all traits studied. High phenotypic and genotypic variances was recorded for yield/plot, number of pods/plant and plant height The efficiency of recurrent selection was proven by the result of high heritability in broad sense for traits such as TSW, number of primary and secondary branch as well as yield per plot. Six yellow seeded and productive genotypes from the recurrent selections lines sourced from cross S-67 X Holetta-1 was found and promoted to national variety trials. According to combined analysis of the multi-location trial, two genotypes, S-67XHoletta-1/7/2/14/2/28/2 and S-67x Holetta-1/9/2/18/2/45/3 were significantly outsmart the existing yellow seeded variety (yellow doddola) with yield advantage of $28 \%$ and $22 \%$, respectively. These advanced genotypes scored $47 \%$ oil content which exceeds yellow doddola by 6 to $7 \%$. The two yellow seeded Ethiopian mustard genotypes were released and registered as improved varieties which could be used to address the existing export demand of Ethiopian mustard for oleo-chemical industries and beyond.
\end{abstract}

Keywords: Ethiopian mused, yellow seed, recurrent selection, variability, heritability, seed yield and oil content.

Abbreviations: CSA: Central Statistical Authority, MOA: Ministry of Agriculture, HARC: Holetta Agricultural Research Center, SAS: Statistical Analysis System

\section{INTRODUCTION}

Ethiopian mustard (Brassica carinata) is an important oil crop of Ethiopian origin and it has been grown in Ethiopia since antiquity both as an oilseed and vegetable crop. The crop is best grown in the mid to high altitude (2000 to $2600 \mathrm{~m}$ ) areas on more fertile, well-drained soil often close to homestead. The major Ethiopian mustard growing areas are located in Arsi, Bale, Gonder, Gojam, Wello, ShewaSidamo and Wellega and about 550,000-750,000 quintals in areas ranges 30,000 to 45,000 ha produced in Ethiopia for the last five years (CSA 2011/12 - 2015/16). Traditionally, Ethiopian mustard also called 'Gomenzer' in Amharic are used to grease a bread baking clay pan used for baking traditional Ethiopian food "enjera", to cure certain ailments or stomach upsets and to prepare some beverages. The leaves of Ethiopian musard plants are good sources of vegetable which has less bitterness, rich in vitamin $\mathrm{C}$ and $\mathrm{K}$, beta carotene, as well as cancer-fightinganti-oxidants [1]. Besides, the crop is used in the farming systems, especially in large scale farms as a break crop for cultivation of cereals with comparable ecological amplitude [2]. Despite its anti-nutritional chemical constituents (i.e. high erucic in its oils and glucosinolate level in the meal) hampers for the utilization 
of the Ethiopian mustard for edible oil and feed for livestock, currently the crop has been demanded for export for its erucic acid which is used as applicable for oleo-chemical industries and in production of derived compounds (eg. behenic, brassilic and pelargonic acid). Studies have also indicated that high glucosinolatecan efficiently control not only weeds but also other soil-borne pests [3].

Despite its versatile use of the crop, there are limited improve varieties of Ethiopian mustard with high oil content and seed yield. The principal aim of oilseed brassica breeding is, thus, to avail high yielding and better quality varieties though variety development or introduction which are adaptable to potential growing areas. A number of breeding activities were carried out for the last three decades and so far eight Ethiopian mustard varieties had been released of which only the variety, yellow doddola is very popular [4]. This variety has been widely grown by state farms as a rotation crop with wheat and faba bean especially at Arsi Zone of Oromia region.

Most landraces of Ethiopian mustard have mixed seed color with somehow light brown dominated colour and their seed yield usually very low , not more than $10 \mathrm{q} / \mathrm{ha}$ [5]. Despite their mixed colour of S-67 and Holetta-1, the two varieties have found to be productive as compared to the local landraces. Seeds of Ethiopian mustard contain 37 to $44 \%$ oil in its seed depending on the genotype and the environment [6]. The seed colour of Ethiopian mustard is associated with the presence and absence of brown and/or black pigment in the seed coat. The absence of pigments results in a translucent seed coat which allows the color of the yellow embryo to be seen [7]. According to previous studies by GetinetAlemaw [8], yellow seed coat in Brassica carinata is positively correlated with high oil content, protein and higher seed weight. Yellow doddola is the only yellow seeded Ethiopian mustard variety which was released 30 years back. The productivity this variety, however, is stated to decline due to poor resistance to diseases such as downy mildew and leaf spot. It is thus necessary to breed yellow seeded Ethiopian mustard varieties that could be alternative or replacing the existing yellow seeded variety, yellow doddola. The aim of this paper tries to present the step-wise breeding efforts of Brassica carination develop yellow seeded varieties with high seed yield and oil content.

\section{MATERIALS AND MeTHODS}

\subsection{Crossing and Selection}

Several crosses composed of ten groups had been made among the adapted varieties of Ethiopian mustard as well as introduced oilseed brassica lines from Brail and Pakistan at Holetta Agricultural Research Center (HARC) in 2010/11 both in the main and off-seasons. During the second cropping season, one hundred twenty single plants were selected from those crosses at $F_{2}$ and subsequent generations $\left(\mathrm{F}_{3}-\mathrm{F}_{5}\right)$ and the seeds were harvested and kept separately. Seeds of these plants along with seeds from pervious single plant selections from yellow doddola, Holetta- 1 and local collections were tested in plant to row bases in 2011/12 while keeping ruminant seeds. Second cycle selection was made in terms of stand, diseases resistance and vigorous growth on the field and later in the laboratory in terms of seed colour. Keeping one half of the seed from each selected plant, the third cycle of selection were conducted in 2013/14 from progeny testing made by planting 90 single plants on a plant-to-row basis with two rows for each progeny. Of which 64 lines from the ten group of crossing materials and three groups of single plant selections were taken in terms of their stand, uniformity, pod length with assumption of more seed per plant, resistance to lodging and shattering, tolerance to pests and heavy thousands seed weight. Variability of the eight important traits was analyzed using simple analysis of variance indicated below:-

\begin{tabular}{|c|c|c|}
\hline Source & Degree of freedom & Error mean square(EMS) \\
\hline Replication & $r-1$ & $\delta^{2}+r \delta g^{2}$ \\
\hline Genotype & $g-1$ & $\delta^{2}$ \\
\hline Error & $(r-1)(g-1)$ & \\
\hline
\end{tabular}

\subsection{Estimate of Heritability and Response to Selection}

In order to confirm the efficacy of the recurrent selection and to determine genetic advance of the traits, heritability and response to selection were determined by conducting replicated trials. The selected 64 lines tested using 8x8 simple lattice designs with two replications at HARC in 2014/15. Each line was planted in a plot consisting of 6 rows of $3 \mathrm{~m}$ length and $30 \mathrm{~cm}$ between rows. Data were 
recorded on ten randomly selected plants from four central rows for plant height, number of primary branches/plant, number of secondary branches/plant, number of pods/plant and thousands seed weight. Days to flowering, days to maturity and seed yield were recorded on plot basis. Broad-sense heritability was estimated from standard analysis of variances and calculated based on the formula of Falconer and Mackay [9] as follows: $\mathrm{H}=\mathrm{h}_{\mathrm{b}}^{2}=\left(\sigma_{\mathrm{G}}^{2} / \sigma_{\mathrm{P}}^{2}\right) \times 100$ where $H$ or $\mathrm{h}_{\mathrm{b}}^{2}$ =heritability in broad sense, $\sigma_{G}^{2}=$ genotypic variance and $\sigma_{\mathrm{P}}^{2}=$ phenotypic variance. Based on the assumption of selection intensity of $5 \%(2.063)$ by Allard (1960) and following the procedure of Johnson et al. (1955a), response to selection $(\mathrm{R})$ and genetic advance as percentage of mean (GA \%) are calculated by the formulas : $\mathrm{R}=R=h^{2} S\left(S=\right.$ selection differential) and $G A(\%)=\frac{R}{\mu} * 100$, respectively.

\subsection{Selection of Yellow Seeded Genotypes with High Yield and Oil Content}

Using the ruminant seeds kept during the second cycle of recurrent selection in 2011/12, one hundred thirty lines were planted in single row for analysis of their seed color as pure yellow, brown and mixed (yellow and brown). The plants were covered by cotton bag to prevent cross-pollination during flower bud formation. Those lines with yellow seeded colour were sown in 2012/13 and yellow seeded lines were identified and sown with the same fashion in 2014/15 and selfed and those lines consistently showed yellow seeded colour along with other desirable traits were selected.

\subsection{Conducting Multi-Location Trial}

Seven best performing entries with yellow seed colour promoted from preliminary variety trials were tested at Holetta, Jeldu, Kulumsa, Bekoji , Adet and Sinana against standard check yellow doddola for two years 2015/16 and 2016/17. The entries arranged in Randomized Completely Block Design (RCBD) with four replications. The gross plot size was $2.7 \mathrm{~m}^{2}$ (six rows spaced at $30 \mathrm{~cm}$ and $3 \mathrm{~m}$ long). A seed rate of $10 \mathrm{~kg} / \mathrm{ha}$ and fertiliser rate $46 / 69 \mathrm{~N} / \mathrm{P}_{2} \mathrm{O}_{5} \mathrm{~kg} / \mathrm{ha} \mathrm{N} / \mathrm{P}_{2} \mathrm{O}_{5}$ was applied at planting. Other cultural practices were carried out as per the local recommendation. Seed yield, oil content and other agronomic parameters such as stand, date of $50 \%$ flowering, disease score, $90 \%$ maturity, plant height, lodging \% and 1000 seed weight were recorded. Data are subjected to analysis of variance using the SAS softwareversion 9.00 [10].

\section{RESULT AND DISCUSSION}

Analysis of variance shows that breeding lines were significantly different $(\mathrm{p}<0.05$ and $\mathrm{p}<0.01)$ for all characters under study (Table 1). The existence of such variability indicates that there is a possibility to exploit the breeding lines for further improvement and even for hybrid variety development. It also observed considerable variability for all the above traits in B. carinata with dissimilar pattern of variation $[11,12]$. The contribution of genetic component for such variability should be confirmed especially for those traits which are correlated to yield and oil content.

Table1. Mean squares of the analysis of variance for morphological character for 64 B.carinata lines.

\begin{tabular}{|c|c|c|c|c|}
\hline Character & Error mean squares & Genotype mean square & Block mean square & $\begin{array}{c}\text { Coefficient of variation } \\
(\%)\end{array}$ \\
\hline 1 & 6.726 & $50.45^{* *}$ & 0.281 & 4.35 \\
\hline 2 & 1.241 & $2.50^{* *}$ & 1.32 & 0.77 \\
\hline 3 & 214.702 & $382.10^{*}$ & 357.781 & 7.43 \\
\hline 4 & 0.384 & $2.33^{* *}$ & 0.075 & 7.17 \\
\hline 5 & 9.810 & $26.67^{* *}$ & 3.445 & 19.36 \\
\hline 6 & 757.62 & $1276.89^{*}$ & 261.061 & 24.34 \\
\hline 7 & 33321.35 & $84940.63^{* *}$ & 88.944 & 8.13 \\
\hline 8 & 0.110 & $0.835^{* *}$ & 0.023 & \\
\hline
\end{tabular}

Note: * and ** Significant at 1.0 and 5.0 percent level of probability and numbers refers to traits where 1 . Days to flowering; 2.Days to maturity; 3.Plant height (cm); 4.Number of primary branches/plant; 5.Number of secondary branches/plant; 6.Number of pods/plant; 7. Yield/plot ( $\mathrm{kg} / \mathrm{ha})$; and 8 . Thousand seed weight $(\mathrm{g})$.

High phenotypic and genotypic variances were obtained for yield/plot, number of pods/plant, and plant height (Table 2). Maximum phenotypic and genotypic coefficients of variation were recorded by number of secondary branches/plant ( 0.680 and 0.625 , respectively) followed by yield per plot $(0.425$ and 0.389 , respectively) and thousands seed weight ( 0.232 and 0.225 , respectively). Heritability in the broad sense estimates were grouped into high $(>50 \%)$, moderate $(20-50 \%)$, and low $(<20 \%)$. High heritability value in broad sense was observed for all characters except days to flowering which 
showed heritability value of $40.62 \%$. Highest heritability was recorded for thousands seed weight implies that the presences of yellow seeded genotypes with high oil content. This was justified by GetinetAlemaw [13] in his finding of yellow seeded B. carinata lines had higher seed weight and similar result was also found for B. junceaby [14]. The present study showed that yield/plot, number of pods/plant, and plant height exhibited high value of genetic advance (Table 2). This indicates that these characters involved additive gene action in their expressions, and can be improved through early generation selection. High heritability along with high genetic advance as percent of mean was recorded by number of secondary branches/plant followed by yield/plot and number of pods/plant. Similar result was found by [15] in his study on B.juncea.

Table2. Component of variance, coefficient of variation, heritability in broad sense and genetic advance for morphological character studied.

\begin{tabular}{|c|c|c|c|c|c|c|c|c|}
\hline Character & PV & GV & EV & PCV & GCV & H (\%) & GA & $\begin{array}{c}\text { GA as \% } \\
\text { mean }\end{array}$ \\
\hline $\mathbf{1}$ & 53.82 & 21.56 & 31.96 & 0.123 & 0.078 & 40.62 & 6.147 & 0.103 \\
\hline $\mathbf{2}$ & 3.12 & 2.503 & 0.621 & 0.012 & 0.011 & 80.12 & 2.921 & 0.02 \\
\hline $\mathbf{3}$ & 489.46 & 382.11 & 107.35 & 0.112 & 0.099 & 78.07 & 35.631 & 0.181 \\
\hline $\mathbf{4}$ & 2.52 & 2.331 & 0.192 & 0.184 & 0.177 & 92.39 & 3.027 & 0.35 \\
\hline $\mathbf{5}$ & 31.57 & 26.67 & 4.9 & 0.68 & 0.625 & 84.48 & 9.792 & 1.185 \\
\hline $\mathbf{6}$ & 1655.69 & 1276.68 & 378.81 & 0.286 & 0.251 & 77.12 & 64.738 & 0.455 \\
\hline $\mathbf{7}$ & 101601.30 & 84940.63 & 16660.68 & 0.425 & 0.389 & 83.60 & 549.75 & 0.733 \\
\hline $\mathbf{8}$ & 0.89 & 0.84 & 0.05 & 0.232 & 0.225 & 94.38 & 1.837 & 0.451 \\
\hline
\end{tabular}

Note: $P V=$ Phenotypic Variance; $G V=$ Genotypic Variance; $E V=$ Environmental Variance; $P C V=$ Phenotypic coefficient of variance; GVC= Genotypic coefficient of variance; $H=$ Heritability (in broad sense) and $G A=$ Getnetic, and numbers refers to where 1=1.Days to flowering; 2.Days to maturity; 3.Plant height (cm); 4.Number of primary branches/plant; 5.Number of secondary branches/plant; 6.Number of pods/plant; 7 . Yield/plot ( $\mathrm{kg} / \mathrm{ha})$; and 8 . Thousand seed weight $(\mathrm{g})$.

Among the 64 genotypes, twelve genotypes were found to be having pure yellow seed colour. Interestingly, most of these genotypes were lines taken from the crossS-67 X Holetta- 1 with high average seed yield (Table 3). There were eleven brown seeded lines obtained from the same number groups of crosses. Of which the lines from the cross ofS-67 x 34477 Pakistan had better seed yield. Despite the presences of one yellow seeded genotypes from each crosses of YD x BRA-1030/79-436, S-67 x 34477 Pakistan and YD x BRA-1030/79-328, and three from yellow doddola selection, their yield relatively minimum and their seed not purely yellow. Rather, the six yellow seeded genotypes from the recurrent selections lines taken from cross S-67 X Holetta-1 were found to be truly yellow and had better average yield and thus promoted to national variety trials.

Table3. Number and yield of B.carinata lines with yellow, brown and mixed seed colour

\begin{tabular}{|c|c|c|c|c|c|c|c|}
\hline \multirow[t]{2}{*}{$\begin{array}{l}\text { No. of } \\
\text { breeding } \\
\text { lines }\end{array}$} & \multirow[t]{2}{*}{ Source } & \multicolumn{3}{|c|}{$\begin{array}{l}\text { No. of lines having seed } \\
\text { coat colour with }\end{array}$} & \multicolumn{3}{|c|}{$\begin{array}{c}\text { Average yield (Kg/ha) lines } \\
\text { within group of crosses } \\
\text { across seed colour }\end{array}$} \\
\hline & & yellow & brown & mixed & yellow & brown & mixed \\
\hline 22 & S-67 X Holetta-1 & 6 & 2 & 14 & 1051.9 & 769.9 & 853.4 \\
\hline 10 & YD x BRA-1030/79-436 & 1 & 0 & 9 & 827.2 & 0 & 726.8 \\
\hline 5 & S-67 x BRA-1030/79-328 & 0 & 3 & 2 & 0 & 637.9 & 2 \\
\hline 5 & S-67 x 34477 Pakistan & 1 & 2 & 2 & 556.8 & 793.6 & 639.2 \\
\hline 5 & S-67 X YD & 0 & 0 & 5 & 0 & 0 & 614 \\
\hline 4 & YD x BRA-1030/79-328 & 1 & 0 & 3 & 308 & 0 & 731.7 \\
\hline 3 & $\begin{array}{c}\text { BRA-1030/79-436 x BRA- } \\
1029 / 79-436\end{array}$ & 0 & 1 & 2 & 0 & 432.8 & 764 \\
\hline 3 & YDSPS & 3 & 0 & 0 & 814.8 & 0 & 0 \\
\hline 2 & S-67 x BRA-1030/79-436 & 0 & 1 & 1 & 0 & 729.9 & 554.7 \\
\hline 2 & LCSPS & 0 & 0 & 2 & 0 & 0 & 755 \\
\hline 1 & S-67 X BRA-1029/79-436 & 0 & 1 & 0 & 0 & 208.5 & 0 \\
\hline 1 & S-67 X SPS 509 & 0 & 1 & 0 & 0 & 531.5 & 0 \\
\hline 1 & Holetta-1 SPS & 0 & 0 & 1 & 0 & 0 & 531.5 \\
\hline
\end{tabular}

Note: $Y D=$ Yellow doddola $; B R A=$ Brazil; $Y D S P S=$ Yellow Doddola Single Plant Selection; LCSPS= Local collection Single Plant Selection; SPS = Single Plant Selection. 
Breeding for Yellow Seeded Ethiopian Mustard (Brassica Carinata) With High Seed Yield and Oil Content at Holetta Agricultural Research Center, Ethiopia

According to the combined analysis, among the six yellow seeded genotypes tested at six locations for two years, the genotypes S-67XHoletta-1/7/2/14/2/28/2 and S-67x Holetta-1/9/2/18/2/45/3 gave higher seed yield as compared to the standard check, yellow doddola (Table 4.) The result indicated that the genotypes S-67XHoletta-1/7/2/14/2/28/2 and S-67x Holetta-1/9/2/18/2/45/3 scored 28\% and $22 \%$ yield advantage over the standard check (yellow doddola), respectively. The above promising yellow seeded Ethiopian mustard genotypes gave around $47 \%$ oil content which was 6-7 \% advantage over yellowdoddola and their seeds were found to be heavier as indicated in TSW data (Table 5). Based on the above merits, the two genotypes were selected as a candidate variety for the release and the variety release committee approved the two genotypes to be registered as improved varieties [16]

Table4. Agronomic performance, pest reaction, seed yield and oil yield of Ethiopian Mustard National Variety Trial at Holetta, Jeldu, Kulumsa, Bekoji, Sinana and Adet combined over two years period (from 2015/16 to 2016/17)

\begin{tabular}{|c|c|c|c|c|c|c|c|c|c|c|}
\hline \multirow[t]{2}{*}{$\begin{array}{c}\text { Plot } \\
\text { No }\end{array}$} & \multirow[t]{2}{*}{ Treatments } & \multicolumn{4}{|c|}{ Agronomic traits } & \multicolumn{3}{|c|}{$\begin{array}{c}\text { *Pest reaction (0- } \\
\mathbf{5 \%})\end{array}$} & \multirow[t]{2}{*}{$\begin{array}{l}\text { Yield } \\
\text { (Kg/ha) }\end{array}$} & \multirow{2}{*}{$\begin{array}{c}\text { Oil } \\
\text { yield } \\
(\mathrm{Kg} / \mathrm{ha})\end{array}$} \\
\hline & & DF & $\overline{\text { DM }}$ & $\begin{array}{l}\mathbf{P H} \\
(\mathbf{c m})\end{array}$ & $\begin{array}{r}\text { ST } \\
(\%)\end{array}$ & DMD & LS & $\overline{\mathbf{A P}}$ & & \\
\hline $\mathbf{1}$ & $\begin{array}{c}\text { S-67xHoletta- } \\
1 / 7 / 1 / / 13 / 1 / 24 / 2\end{array}$ & 80 & 159 & 179 & 82 & 2.1 & 1.5 & 3.1 & 1602.2 & 73.2 \\
\hline 2 & $\begin{array}{l}\text { S-67XHoletta- } \\
1 / 7 / 1 / / 13 / 1 / 25 / 3\end{array}$ & 78 & 160 & 177 & 81 & 2.1 & 1.6 & 2.8 & 1683.5 & 77.9 \\
\hline 3 & $\begin{array}{l}\text { S-67XHoletta- } \\
\text { 1/7/2/14/2/28/2 }\end{array}$ & 77 & 157 & 181 & 86 & 0.9 & 1.3 & 1.5 & 2394.9 & 112.1 \\
\hline 4 & $\begin{array}{l}\text { S-67XHoletta- } \\
\text { 1/9/2/18/2/32/1 }\end{array}$ & 78 & 159 & 182 & 82 & 2.2 & 1.8 & 3.1 & 1633.1 & 75.1 \\
\hline 5 & $\begin{array}{l}\text { S-67XHoletta- } \\
1 / 9 / 2 / 18 / 2 / 36 / 4\end{array}$ & 77 & 159 & 179 & 81 & 2.0 & 1.7 & 3.1 & 1705.6 & 77.9 \\
\hline 6 & $\begin{array}{c}\text { Y.DXBAR-1030/79- } \\
436 / 2001 / 6 / 2 / 11 / 2 / 17 / 3\end{array}$ & 74 & 158 & 171 & 81 & 2.0 & 1.4 & 3.2 & 1791.6 & 80.6 \\
\hline 7 & $\begin{array}{l}\text { S-67xHoletta- } \\
1 / 9 / 2 / 18 / 2 / 45 / 3\end{array}$ & 75 & 158 & 164 & 85 & 1.3 & 0.9 & 1.8 & 2280.4 & 106.2 \\
\hline 8 & Yellow Dodolla & 78 & 161 & 175 & 82 & 1.8 & 1.7 & 2.3 & 1863.3 & 81.7 \\
\hline & Mean & 77 & 159 & 176.0 & 82.6 & 1.8 & 1.5 & 2.6 & 1869.3 & 85.6 \\
\hline & LSD (0.05) & 5 & 8 & 11.7 & 6.0 & 0.6 & 0.7 & 0.7 & 371.7 & \\
\hline & $\mathrm{CV}$ & 11 & 8 & 10.6 & 11.7 & 30.4 & $\begin{array}{c}42 . \\
8\end{array}$ & $\begin{array}{c}24 . \\
1\end{array}$ & 31.9 & \\
\hline
\end{tabular}

Note: $D F=$ Date of flowering, DM=Date of maturity, $P H=$ Plant height. DMW= Downey mildew, LS=Leaf spot and Aph=Aphids, * Pest reaction data analyzed only for Holetta and Jeldu.

Table5. Oil content and thousands seed weight of Ethiopian mustard genotypes

\begin{tabular}{|c|c|c|c|c|c|c|c|}
\hline \multirow{2}{*}{$\begin{array}{l}\text { Plot } \\
\text { No. }\end{array}$} & \multirow[t]{2}{*}{ Treatments } & \multicolumn{5}{|c|}{ Oil content $(\%)$ across testing locations } & \multirow[t]{2}{*}{ *TSW (g) } \\
\hline & & Holetta & Kulumsa & Bekoj & Sinana & Mean & \\
\hline $\mathbf{1}$ & S-67xHoletta-1/7/1//13/1/24/2 & 47.5 & 49.6 & 49.4 & 36.2 & 45.7 & 4.0 \\
\hline 2 & S-67XHoletta-1/7/1//13/1/25/3 & 47.1 & 47.8 & 47.2 & 43.0 & 46.3 & 3.8 \\
\hline 3 & S-67XHoletta-1/7/2/14/2/28/2 & 48.8 & 46.5 & 49.5 & 42.5 & 46.8 & 4.2 \\
\hline 4 & S-67XHoletta-1/9/2/18/2/32/1 & 49.9 & 47.4 & 47.7 & 39.0 & 46.0 & 3.3 \\
\hline 5 & S-67XHoletta-1/9/2/18/2/36/4 & 49.3 & 47.3 & 49.5 & 36.5 & 45.7 & 3. \\
\hline 6 & Y.DXBAR-1030/79-436/2001/6/2/11/2/17/3 & 44.8 & 46.8 & 49.3 & 39.1 & 45.0 & 3.8 \\
\hline 7 & S-67xHoletta-1/9/2/18/2/45/3 & 48.5 & 46.3 & 49.1 & 42.3 & 46.6 & 5.2 \\
\hline 8 & Yellow Doddola & 44.2 & 45.5 & 47.0 & 38.6 & 43.8 & 4.0 \\
\hline & Mean & 47.5 & 47.2 & 48.6 & \begin{tabular}{|c|}
39.7 \\
\end{tabular} & & \\
\hline
\end{tabular}

\section{CONCLUSIONS}

This study indicates that the existence of considerable variability of considerable genetic variation among the breeding lines for the traits under study, which can be used for further selection and hybridization. Traits such as thousands seed weight, number of primary and secondary branch as well as yield per plot showed high heritability estimate in broad sense. This implies that efficiency of recurrent selections for those traits. Besides, selection at early generation stage can be made for those 
traits with high heritability estimate along with high genetic advance such as yield per plot, pod per plant and plant height since additive gene action is pronounced in these traits. Breeding for yellow seed colour in Ethiopian mustard is not only for the colourperse but also to grasp other important traits due the positive association of yellow seed coat with high oil content and protein. The release and registration of the two yellow seeded genotypes (S-67XHoletta-1/7/2/14/2/28/2 and S-67x Holetta$1 / 9 / 2 / 18 / 2 / 45 / 3$ ) is a good opportunity for the presence of $\mathrm{B}$. carinatavarieties with high seed yield and oil content which could be used for oleo-chemical industries, export and other unexploited benefit of the crop.

\section{ACKNOWLEDGEMENTS}

We would like to acknowledge research technicians of Oilseeds Research Program who manage the trials to be successfully accomplished. We would like to thank collaborative research centers in handling the multi-location trials. This work was supported by capital budget of Ethiopian Institute of Agricultural Research and thus we appreciated the continued support of the EIAR for Ethiopian mustard improvement.

\section{REFERENCES}

[1] Mnzava, N.A. and Schippers, R.R., Brassica carinataA.Braun in: van der Vossen, H.A.M. \&Mkamilo, G.S. (Editors). PROTA 14: Vegetable oils/Oléagineux. [CD-Rom]. PROTA, Wageningen, Netherlands, $3(2002)$

[2] Oleszek, W., Allelopathic effects of volatiles from some cruciferae species on lettuce, barnyard grass and wheat growth. Plant and Soil. 102: 271-273, (1987).

[3] Brown, P.D. and Morra M. J., Control of soil-borne plant pests using glucosinolate-containing plants. Advances in Agronomy.61: 167-231, (1997)

[4] Ministry of Agriculture (MoA). Plant Variety Release Protection and Seed Quality Control Directorate, Variety Registry Bulleting No.15, (2015).

[5] AdefrisTeklewold, (2005). Diversity Study Based on Quality Traits and RAPD Marker and Agronomic Traits in Ethiopian Mustard (Brassica carinataA. Braun). Investigation of Heterosis in Ethiopian Mustard CuvillierVerlag, Göttingen, Germany. PhD dissertation, ISBN 3-86573- 529-4, (2005)

[6] AdefrisTeklewold, BulchaWoyessa, MisteruTesfaye, AdugnaWakjira, SilivesterN.Samali and Chris O. Ojiewo., Good Agricultural Practices for Production of Ethiopian Mustard (Brassica carinataA. Braun) in Sub-Saharan Africa. In: Proceeding of Good Agricultural Practices for Africa Indigenous Vegetables, Nono-Womdim, C. Ojiewo,M. Abang, Mel O. Oluoch eds.), ISSN 1813-9205,ISBN 978906605694 7, ScriptaHorticulturaeNumber 15, (2009)

[7] Getinet A and G Rakow. Repression of seed coat pigmentation in Ethiopian Mustard. Can J. Plant Sci. 77:501-505. (1997)

[8] GetinetAlemaw. Inheritance of seed coat color in Brassica carinataA. Braun and an examination of seed quality parameters and their transfer from related species (B. napusL. and B. junceaCzern\&Coss). MSc Thesis, Department of Crop Science and Plant Ecology, University of Saskatchewan, Saskatoon, SK. 105 pp. (1986)

[9] Falconer, D.S and Mackay, T.F.C., Introduction to quantitative genetics. Essex, UK, Longman, (1996)

[10] SAS Institute. SAS/STAT guide for personal computers, version 9.00 edition. Cary, NC: SAS Institute Inc. (2002)

[11] Muthoni, J., Characterization of Ethiopian mustard (Brassica carinataA. Braun) lines for vegetative agro morphological traits at Arusha, Tanzania. J. Hort. For., (2): 1-6. (2010).

[12] MisteruTesfaye and YaredSemahegn. Genetic Variability of Ethiopian Mustard (Brassica carinataA.Brun) Accessions Based on Some Morphological Characters, International Journal of Plant Breeding and Genetics 7 (3): pp.171 (2013)

[13] GetinetAlemaw. Inheritance of seed coat color in Brassica carinataA. Braun and an examination of seed quality parameters and their transfer from related species (B. napusL. and B. junceaCzern\&Coss). MSc Thesis, Department of Crop Science and Plant Ecology, University of Saskatchewan, Saskatoon, SK. 105 pp. (1986)

[14] Bind D., Singh D., and Dwivedi V.K., Genetic variability and character association in Indian mustard [Brassica juncea(1) czerns\&coss], Agricultural Molecular Plant Breeding 2016, Vol.7, No.20, 18,http://mpb.biopublisher.ca.,Science Digest, 34(3): 183-188. (2014) 
[15] Synrem G. J., Rangare N. R., Myrthong I., and Bahadure D.M., Variability studies in Intra specific crosses of Indian mustard [Brassica juncea (L.) Czern and Coss.] genotypes, IOSR Journal of Agriculture and Veterinary Science, 7: 29-32. (2014)

[16] Ministry of Agriculture (MoA). Plant Variety Release Protection and Seed Quality Control Directorate, Variety Registry Bulleting No.15, (2017), In Press.

Citation: Misteru Tesfaye, et.al, (2019). "Breeding for Yellow Seeded Ethiopian Mustard (Brassica Carinata) With High Seed Yield and Oil Content at Holetta Agricultural Research Center, Ethiopia" International Journal of Research Studies in Agricultural Sciences (IJRSAS), 5(3), pp. 1-7, http://dx.doi.org/ 10.20431/2454-6224.0503001

Copyright: (C) 2019 Authors. This is an open-access article distributed under the terms of the Creative Commons Attribution License, which permits unrestricted use, distribution, and reproduction in any medium, provided the original author and source are credited. 